\title{
HUBUNGAN PERSEPSI MASYARAKAT DENGAN PENERIMAAN VAKSIN COVID 19 DI KECAMATAN WUA WUA KOTA KENDARI TAHUN 2021
}

\author{
Suhadi $^{1}$, Lade Albar Kalza ${ }^{2}$, La Ode Liaumin Azim ${ }^{3}$ \\ ${ }^{1,2,3}$ Fakultas Kesehatan Masyarakat Universitas Halu Oleo, Kendari
}

\begin{abstract}
Covid -19 are a large family of viruses that cause illness ranging from mild to severe symptoms. There are at least two types of coronavirus that are known to cause diseases that can cause severe symptoms such as Middle East Respiratory Syndrome (MERS) and Severe Acute Respiratory Syndrome (SARS). To find out the relationship between Knowledge and Public Perception in Receiving the Covid 19 Vaccine in Wua Wua District, Kendari City. Quantitative desain research with cross sectional approach. The research population is all people living in Wua-Wua District, Kendari City. Sampling was based on proportional random sampling technique. With a total sample of 99 respondents. The results of the chi square statistical test to test there is a relationship between knowledge and vaccine information obtained a value of $=0.026$. There is no relationship between knowledge and economic status, the value $=0.639$. There is no relationship between knowledge and access, the value $=0.116$. The Wua-wua District Government is expected to coordinate with the Puskesmas to provide akuration complete information related to the safety of vaccine use, effectiveness and equitable distribution of vaccines.
\end{abstract}

Keywords: Vaccine information, economic status and access

\section{A. PENDAHULUAN}

World Health Organization memberikan nama virus baru yang disebut sindrom pernapasan akut parah sarcov-2 (SARS-CoV-2) dan nama penyakitnya penyakit coronavirus 2019 (COVID-19). pertamanya, penyakit ini dinamakan sementara sebagai 2019 novel coronavirus (2019-nCoV), kemudian WHO mengumumkan nama baru pada 11 Februari 2020 yaitu Coronavirus Disease (COVID-19) yang disebabkan oleh virus Severe Acute Respiratory Syndrome Coronavirus-2 atau biasa disebut SARS-CoV-2 (WHO, 2021).

Pemimpin pemerintahan juga terus mendorong dan memfasilitasi peningkatan kemampuan Puskesmas, laboratorium rujukan, serta laboratorium jejaring rujukan dalam rangka memperkuat upaya pelayanan COVID-19. Fasilitas pelayanan kesehatan dalam situasi pandemi tetap harus memperhatikan mutu dan keselamatan pasien, sehingga diperlukan adanya pedoman. Pedoman ini juga mencakup peran perubahan teknis pelayanan dan konsultasi medis non-COVID-19 pada masa pandemi, sehingga dapat menjadi landasan untuk senantiasa memberikan mutu layanan terbaik bagi fasilitas pelayanan kesehatan, tenaga medis, tenaga kesehatan, dan masyarakat (Kemenkes RI, 2020).

Berdasarkan hasil laporan vaksinasi Covid 19 Kota Kendari tanggal 06 September 2021, dimana total yang sudah di vaksin sebanyak 265.147 orang yang terdiri dari Tenaga kesehatan sebanyak 4.151 orang, pelayanan publik sebanyak 37.810 orang, lansia sebanyak 17.040 orang, masyarakat umu dan rentan sebanyak 170.409 
orang serta remaja sebanyak 35.737 orang (Satuan Tugas Penanganan Covid-19 (SATGAS COVID-19), 2021).

Berdasarkan paparan pada uraian diatas, maka rumusan masalah dalam penelitian ini adalah bagaimana Hubungan Pengetahuan Dengan Persepsi Masyarakat Dalam Penerimaan Vaksin Covid 19 Di Kecamatan Wua Wua Kota Kendari Tahun 2021 ?

Tujuan dilakukan penelitian adalah untuk mengetahui gambaran Pengetahuan Dengan Persepsi Masyarakat Dalam Penerimaan Vaksin Covid 19 Di wilayah Kecamatan Wua Wua Kota Kendari Provinsi Sulawesi Tenggara.

\section{B. TINJAUAN PUSTAKA}

Melalui pandangan seseorang dapat menyadari, dapat mengerti tentang keadaan diri manusia yang bersangkutan. Pandangan itu merupakan aktivitas yang integritas, maka seluruh apa yang ada dalam diri individu seperti perasaan, pengalaman, kemampuan berpikir, kerangka acauan dan aspek-aspek lain yangada dalam diri 18 individu masyarakat akan ikut berperan dalam pandangan tersebu (Notoatmodjo, 2012).

Berkaitan dengan hal defenisi masyarakat dalam kamus bahasa Inggris, masyarakat disebut society community asal katanya socius yang berarti kawan. Arti yang lebih khusus,bahwa masyarakat adalah kesatuan sosial yang mempunyai kehidupan jiwa sepertiadanya ungkapan-ungkapan jiwa rakyat, kehendak rakyat, kesadaran masyarakat dan sebaginya. Sedangkan jiwa masyarakat ini merupakan potensi yang berasal dari unsur-unsur masyarakat meliputi pranata, status dan peranan sosial. Sehingga para pakar sosiologi seperti Mac Iver, J.L Gillin memberikan pengertian bahwa masyarakat adalah kumpulan individu-individu yang saling bergaul berinteraksi karena mempunyai nilai-nilai, norma-norma, cara-cara dan prosedur yang merupakan kebutuhan bersama berupa suatu sistem adat istiadat tertentu yang bersifat kontinyu dan terikat oleh suatu identitas bersama Defenisi pengetahuan adalah sebagian ingatan atas hal-hal yang telah dipelajari dan ini mungkin menyangkut mengingat kembali sekumpulan bahan yang luas dari hal-hal yang terperinci untuk teori, tetapi apa yang diberikan adalah menggunakan ingatan untuk keterangan yang sesuai(Notoatmodjo, 2012).

Sedangkan pengetahuan diartikan sebagai hasil tahu dan ini terjadi setelah seseorang melakukan penginderaan terhadap obyek tertentu. Jadi pengetahuan adalah apa yang telah diketahui oleh setiap individu setelah penginderaan terjadi melalui panca indera manusia, yakni indera penglihatan, pendengaran, penciuman, rasa dan raba. Sebagian besar pengetahuan manusia diperoleh melalui mata dan telinga. Selanjutnya, Rusli Ngatimin dengan menggunakan teori Benjamin S. Bloom, mengemukakan bahwa pengetahuan merupakan bagian dari "cognitif domain" yang sangat penting untuk terbentuknya tindakan seseorang (overt behavior)(Notoatmodjo, 2012).

Produk Vaksin Covid-19 produksi Sinovac telah mendapatkan persetujuan Emergency Use Authorization (EUA) atau izin penggunaan dalam kondisi emergency yang diterbitkan oleh Badan Pengawas Obat dan Makanan. Sesuai keterangan resmi dari BPOM RI, pendaftaran vaksin bernama CoronaVac itu dilakukan PT Bio Farma. 


\section{METODE PENELITIAN}

Penelitian ini termasuk dalam jenis penelitian analitik observasional dengan metode kuantitatif dengan metode pendekatan cross sectional.

Populasi penelitian ini adalah semua Masyarakat yang tinggal di Kecamatan WuaWua Kota Kendari. Cara mendapatkan sampel berdasarkan teknik proportional random sampling. Setelah dilakukan penghitungan diperoleh sampel yang diambil sebanyak 99 responden.

Variable yang diukur dalam penelitian ini yaitu kategori Pengetahuan Dengan Persepsi Masyarakat Dalam Penerimaan Vaksin Covid 19 Di wilayah administrasi distric Wua Wua Kota Kendari Sulawesi Tenggara, maka akan dilihat dengan mencari data di masyarakat tentang persepsi masyarakat, informasi vaksin, jenis kelamin, status ekonomi dan akses.

Analisis data yang dipakai yakni analisis multivariat dan bivariat dapat melihat hubungan pengetahuan dengan persepsi masyarakat dalam penerimaan vaksin covid 19 di kelurahan Wua-Wua Kota Kendari

\section{HASIL PENELITIAN}

\section{Umur Responden}

Tabel 1. Distribusi Responden Berdasarkan Umur di Kecamatan Wua-Wua Kota Kendari

\begin{tabular}{|c|c|c|}
\hline Kelompok Umur (Tahun) & Responden & Persentase \\
\hline $18-25$ & 7 & 7,1 \\
\hline $26-35$ & 6 & 6,1 \\
\hline $36-45$ & 22 & 22,2 \\
\hline $46-55$ & 54 & 54,5 \\
\hline $56-65$ & 10 & 10,1 \\
\hline Total. & $\mathbf{9 9}$ & $\mathbf{1 0 0 .}$ \\
\hline
\end{tabular}

Berdasar tabel 1, menunjukkan bahwa dari 99 responden distribusi berdasarkan umur yang paling banyak adalah umur 46-55 tahun yaitu sebanyak 54 $(54,05 \%)$, dan yang paling sedikit adalah usia 26-35 sebanyak $6(6,1 \%)$ 


\section{Pendidikan}

Tabel 2. Distribusi Responden Berdasarkan Pendidikan di Kecamatan Wua-wua

\begin{tabular}{|c|c|c|}
\hline Pendidikan & Responden & Persentase \\
\hline SD/ Sederajat & 11 & 11,1 \\
\hline Tamat SMP & 25 & 25,3 \\
\hline Tamat SMA & 21 & 21,2 \\
\hline Mahasiswa/ Sarjana & 38 & 38,4 \\
\hline Master/Doktor & 04 & 4,0 \\
\hline Total. & $\mathbf{9 9}$ & $\mathbf{1 0 0 .}$ \\
\hline
\end{tabular}

Berdasarkan tabel 2, menunjukkan adanya distribusi responden berdasarkan pendidikan yang paling banyak adalah Mahasiswa/ Sarjana yaitu sebanyak 38 orang $(38,4 \%)$ dan yang paling sedikit ialah Master/ Doktoral yaitu sebanyak 4 orang $(4,0 \%)$.

\section{Pekerjaan}

Tabel 3. Distribusi Responden Berdasarkan Pekerjaan di Kecamatan Wuawua

\begin{tabular}{|c|c|c|}
\hline Pekerjaan & Responden & Persentase \\
\hline Pelajar/ Mahasiswa & 15 & 15,2 \\
\hline Honorer/ PNS & 14 & 14,1 \\
\hline Petani & 5 & 5,1 \\
\hline Wiraswasta & 20 & 20,2 \\
\hline Buruh Bangunan & 2 & 2,0 \\
\hline IRT & 43 & 43,4 \\
\hline Total & $\mathbf{9 9}$ & $\mathbf{1 0 0 .}$ \\
\hline
\end{tabular}

Berdasarkan tabel 3, menunjukkan bahwa distribusi responden berdasarkan pekerjaan yang paling banyak adalah IRT yaitu sebanyak 43 orang $(43,4 \%)$ dan yang paling sedikit adalah Buruh Bangunan yaitu sebanyak 2 orang $(2,0 \%)$. 


\section{Analisis Bivariat}

1. Hubungan pengetahuan dengan informasi vaksin terhadap penerimaan vaksin Covid 19 di Kecamatan Wua-wua Kota Kendari

Tabel 4. Hubungan Pengetahuan dengan Informasi vaksin terhadap penerimaan vaksin Covid 19 di Kecamatan Wua-wua Kota Kendari

\begin{tabular}{|c|c|c|c|c|c|c|c|}
\hline \multirow{3}{*}{ Informasi vaksin } & \multicolumn{4}{|c|}{ Pengetahuan } & \multicolumn{2}{|c|}{ Total } & \multirow{3}{*}{ Uji Statistik } \\
\hline & \multicolumn{2}{|c|}{ Baik } & \multicolumn{2}{|c|}{ Kurang } & \multirow[b]{2}{*}{$\mathbf{n}$} & \multirow[b]{2}{*}{$\%$} & \\
\hline & $\mathbf{N}$ & $\%$ & $\mathbf{n}$ & $\%$ & & & \\
\hline sosial/ & 24 & 60,0 & 22 & 7,3 & 46 & 46,5 & $\mathrm{X}^{2}$ hit $=4,943$ \\
\hline $\begin{array}{l}\text { Komunikasi } \quad \text { Tatap } \\
\text { Muka }\end{array}$ & 16 & 40,0 & 37 & 62,7 & 53 & 53,5 & $\begin{array}{l}X^{2} t a b=3,481 \\
\emptyset=0,026\end{array}$ \\
\hline Total & 40 & 100 & 59 & 100 & 99 & 100 & \\
\hline
\end{tabular}

Tabel 4 menunjukkan bahwa dari total 99 responden pada kelompok pengetahuan baik tentang informasi vaksin yang mendengar melalui media sosial/FB/WA sebanyak 24 orang $(60,0 \%)$ dan memiliki tingkat pengetahuan yang kurang sebanyak 22 orang $(37,3 \%)$, sedangkan pada kelompok yang memiliki pengetahuan baik tentang informasi vaksin melalui tatap muka sebanyak 16 orang (40,0 \%) dan memiliki pengetahuan kurang baik sebanyak 37 orang $(62,07 \%)$.

Hasil analisis uji statistik menggunakan analisis Chi- Square diperoleh nilai atau nilai signifikansi $X^{2}$ hit=4,943 dan $X^{2}$ tab=3,481 dengan $\emptyset=0,026$ dan $\alpha=0,05$. Nilai $\mathrm{P}$ lebih kecil dari $\alpha$, maka kesimpulannya adalah ada hubungan antara Pengetahuan dengan informasi vaksin terhadap penerimaan vaksin Covid 19 di Kelurahan Wua-wua Kota Kendari.

2. Hubungan pengetahuan dengan status ekonomi terhadap penerimaan vaksin Covid 19 di Kecamatan Wua-wua Kota Kendar

Tabel 5. Hubungan Pengetahuan dengan status ekonomi terhadap penerimaan vaksin Covid 19 di Kecamatan Wua-wua Kota Kendari

\begin{tabular}{|c|c|c|c|c|c|c|c|}
\hline \multirow{3}{*}{$\begin{array}{l}\text { Status } \\
\text { ekonomi }\end{array}$} & \multicolumn{4}{|c|}{ Pengetahuan } & \multicolumn{2}{|c|}{ Total } & \multirow{3}{*}{ Uji Statistik } \\
\hline & \multicolumn{2}{|c|}{ Baik } & \multicolumn{2}{|c|}{ Kurang } & \multirow[t]{2}{*}{$\mathbf{n}$} & \multirow[t]{2}{*}{$\%$} & \\
\hline & $\mathbf{n}$ & $\%$ & $\mathbf{N}$ & $\%$ & & & \\
\hline Cukup & 9 & 22,5 & 11 & 18,6 & 20 & 20,2 & X2hit $=2,220$ \\
\hline Kurang & 31 & 77,5 & 48 & 79,8 & 79 & 79,8 & $\mathrm{X} 2 \mathrm{tab}=3,481$ \\
\hline Total & 40 & 100 & 59 & 100 & 99 & 100 & $\emptyset=0,639$ \\
\hline
\end{tabular}


Tabel 5 menunjukkan bahwa dari total 99 responden pada kelompok status ekonomi cukup yang mendapat pengetahuan baik sebanyak 9 orang $(22,5 \%)$ dan memiliki tingkat pengetahuan yang kurang baik sebanyak 11 orang $(18,6 \%)$, sedangkan pada status ekonomi kurang yang mendapat pengetahuan baik sebanyak 31 orang $(77,5 \%)$ dan memiliki pengetahuan tidak baik sebanyak 48 orang $(79,8$ $\%)$.

Hasil analisis pengujian statistik menggunakan analisis Chi- Square diperoleh nilai atau nilai signifikansi $X^{2} h i t=2,220$ dan $X^{2} \operatorname{tab}=3,481$ dengan $\varnothing=$ 0,639 dan $\alpha=0,05$. Nilai P lebih besar dari $\alpha$, maka kesimpulannya adalah tidak ada hubungan antara Pengetahuan dengan status ekonomi terhadap penerimaan vaksin Covid 19 di Kelurahan Wua-wua Kota Kendari.

Ada hubungan antara tinggi status ekonomi masyarakat dengan besarnya permintaan akan pemeliharaan kesehatan, terutama dalam hal pelayanan kesehatan. Pada masyarakat berpendapatan rendah, akan mencukupi kebutuhan barang terlebih dahulu setelah kebutuhan akan barang tercukupi maka akan memenuhi kebutuhan kesehatan. pembiayaan kesehatan umumnya meningkat sesuai dengan peningkatan status ekonomi. Orang yang berpendapatan cukup cenderung lebih sering dan lebih ekstensif dalam layanan tenaga kesehatan. Orang yang berpendapatan tinggi juga lebih sering memeriksa dan memelihara kesehatan dibanding dengan individu yang pendapatan kurang. Notoatmodjo (2012)..

3. Hubungan pengetahuan dengan akses terhadap penerimaan vaksin Covid 19 di Kecamatan Wua-wua Kota Kendar

Tabel 6. Hubungan Pengetahuan dengan akses terhadap penerimaan vaksin Covid 19 di Kecamatan Wua-wua Kota Kendari

\begin{tabular}{|c|c|c|c|c|c|c|c|}
\hline \multirow{3}{*}{ Akses } & \multicolumn{4}{|c|}{ Pengetahuan } & \multicolumn{2}{|c|}{ Total } & \multirow{3}{*}{ Uji Statistik } \\
\hline & \multicolumn{2}{|c|}{ Baik } & \multicolumn{2}{|c|}{ Kurang } & \multirow{2}{*}{$\mathbf{n}$} & \multirow{2}{*}{$\%$} & \\
\hline & $\mathbf{n}$ & $\%$ & $\mathbf{n}$ & $\%$ & & & \\
\hline Terjangkau & 18 & 45,0 & 36 & 61,0 & 54 & 54,5 & \multirow{3}{*}{$\begin{array}{c}X^{2} \text { hit }=2,467 \\
X^{2} \text { tab }=3,481 \\
\emptyset=0,116\end{array}$} \\
\hline $\begin{array}{l}\text { Tidak } \\
\text { terjangkau }\end{array}$ & 22 & 55,0 & 23 & 39,0 & 45 & 45,5 & \\
\hline Total & 40 & 100 & 59 & 100 & 99 & 100 & \\
\hline
\end{tabular}

Tabel 6 menunjukkan bahwa dari total 99 responden pada kelompok akses terjangkau yang memiliki pengetahuan baik sebanyak 18 orang $(45,0 \%)$ dan memiliki tingkat pengetahuan yang kurang baik sebanyak 36 orang $(61,0 \%)$, sedangkan pada kelompok akses yang tidak terjangkau yang memiliki pengetahuan baik sebanyak 22 orang $(55,0 \%)$ dan memiliki pengetahuan kurang sebanyak 23 orang $(39,0 \%)$.

Hasil analisis uji statistik menggunakan analisis Chi-Square diperoleh nilai atau nilai signifikansi $X^{2}$ hit=2,467 dan $X^{2}$ tab=3,481 dengan $\emptyset=0,116$ dan $\alpha 0,05$. Nilai $\mathrm{P}$ lebih besar dari $\alpha$, maka kesimpulannya adalah tidak ada hubungan antara 
Pengetahuan dengan akses terhadap penerimaan vaksin Covid 19 di Kelurahan Wua-wua Kota Kendari.

Beberapa masyarakat mengungkapkan bahwa tidak terjangkau layanan vaksinasi itu terjadi di awal-awal pandemi covid 19 kemudian banyak di antara masyarakat yang beranggapan sebagai ibu rumah tangga yang tidak berkepentingan dengan kartu vaksinasi sehingga mereka menolak untuk akses vaksinasi covid 19. Pengetahuan masyarakat yang masih rendah ini menyebabkan petugas kesehatan kesulitan dalam mengajak masyarakat melakukan vaksin sarcov-2 untuk memutuskan penyebab menularnya penyakit dalan penularan demi kekebalan tubuh manusia secara sempurna.

\section{E. PEMBAHASAN}

\section{Pengetahuan}

Pengetahuan sangat penting dalam memberikan wawasan terhadap sikap dan tindakan (perbuatan) seseorang. Pada penelitian ini di dapatkan bahwa pengetahuan yang paling banyak adalah pengetahuan masyarakat yang masih kurang yaitu sebanyak 59 orang $(59,6 \%)$ dan pengetahuan baik adalah $40(40,4 \%)$.

Peningkatan pengetahuan memang tidak selalu menyebabkan perubahan perilaku akan tetapi ada hubungan yang positif berkaitan dengan perubahan perilaku. Pengetahuan atau kognitif merupakan domain yang sangat penting dalam membentuk tindakan seseorang (overt behaviour) (Widayanti and Kusumawati, 2021).

.Pengetahuan merupakan faktor risiko untuk mempengaruhi persepsi dan prilaku seseorang. Dikarenakan pengetahuan tentang vaksin covid-19 sangat mempengaruhi seseorang dalam menerima vaksin covid-19, hal ini mungkin saja adanya keterkaitan hubungan tingkat pendidikan dengan pengetahuan seseorang. Semakin baik tingkat pendidikan, maka semakin baik pula tingkat pengetahuan. Selain pendidikan, faktor sosial juga dimungkinkan dapat mempengaruhi tingkat pengetahuan seseorang mengingat orang disekitar dan teman juga memiliki fungsi sebagai penyampaian pesan yang efektif untuk meningkatkan pengetahuan masyarakat dan fungsi orang tua juga sangat efektif dalam memberikan informasi kepada keluarganya, sehingga peningkatan pengetahuan mengarah pada peningkatan persepsi terhadap vaksin covid-19, dimulai dari keluarga dan selanjutnya adanya dorongan-dorongan dari lingkungan sekitar yaitu termasuk gerakan-gerakan kelompok masyarakat. Pengetahuan seseorang dapat bertambah pula dengan cara memperkaya khasanah pengetahuan melalui membaca baik melalui media massa dan media elektrik (internet), sehingga walaupun tanpa melalui pendidikan formal. Pengetahuan seseorang dapat meningkat dengan demikian harapan tentang keberhasilan program imunisasi dapat dicapai melalui kesadaran masyarakat akan dampak imunisasi bagi kesejahteraan masyarakat secara umum dan kesejahteraan anak secara khususnya (Elhadi et al., 2021)

Berdasarkan hasil penelitian ini dapat disimpulkan bahwa pengetahuan seseorang sangat berperan penting dalam penerimaan vaksin covid 19 untuk meminimalisir tingkat resiko dalam penularan covid 19. Masyarakat yang tahu mengenai pentingnya vaksninasi cenderung memiliki sikap dan perilaku yang 
positif dalam membangun persepsi vaksinasi dengan lengkap dari pada responden dengan tingkat pengetahuan yang kurang baik. Di Kecamatan Wua-wua pada umumnya masih banyak masyarakat memiliki pengetahuan yang sangat rendah terhadap vaksinasi covid 19 sehingga penularan covid 19 sangat rentan terhadap masyarakat.

\section{Informasi Vaksin}

Responden Responden diberi pertanyaan seputar ketertarikan terhadap informasi mengenai vaksin COVID-19 dan sumbernya serta saluran komunikasi pilihan mereka. Kebanyakan responden berusia 18 sampai 65 tahun. Sedikit lebih dari separuh responden adalah perempuan.

Berdasarkan informasi vaksin yang paling banyak adalah Media Sosial/ FB/WA yaitu sebanyak 46 orang $(46,5 \%)$ dan informasi vaksin yang paling sedikit melalui komunikasi tatap muka sebanyak 53 orang $(53,5 \%)$.

Informasi dari responden yang takut jarum suntik dan yang pernah mengalami efek samping setelah di vaksinasi. Penelitian ini sejalan dengan penelitian Christina Giambi pada tahun 2012 yang menyatakan bahwa informasi sumbang yang diterima petugas kesehatan serta kurangnya informasi mengenai HPV / kanker serviks merupakan penghalang yang lebih umum dilaporkan terhadap vaksinasi HPV(Achadi, Anhari Puspasari, 2021).

Beberapa responden mempertanyakan proses uji klinis vaksin dan keamanannya yang singkat. Keandalan penyedia vaksin dinilai penting dan banyak yang menyatakan bersedia menerima vaksin jika Indonesia yang memproduksinya karena terkait dengan kondisi iklim. Responden juga berharap pemimpin daerah maupun pemimpin kelurahan menjadi teladan, misalnya, dengan menjadi yang pertama divaksin sebelum vaksinasi massal dilakukan. Banyak responden yang tidak percaya bahwa COVID-19 (SARS-CoV-2) nyata ataupun kemungkinannya untuk menular dan mengancam kesehatan masyarakat. Beberapa responden menyatakan bahwa pandemi adalah produk propaganda, konspirasi, hoaks, dan/atau upaya sengaja untuk menebar ketakutan melalui media untuk dapat keuntungan serta informasi bagi masyarakat yang tidak melakukan vaksinasi maka tidak dapat bantuan sosial dari pemerintah.

\section{Status ekonomi}

Berdasarkan hasil penelitian didapatkan bahwa status ekonomi untuk masyarakat kecamatan Wua-wua yang kategori tidak cukup sebanyak 79 orang $(79,8 \%)$ dan yang cukup sebanyak 20 orang $(20,2 \%)$. Hal ini menandakan bahwa responden berpenghasilan rendah tingkat pengetahuannya terkait vaksin paling rendah. Tingkat pengetahuan tentang informasi tersebut cenderung naik sesuai dengan tingkatan status ekonomi responden. Masyarakat dengan pendapatan yang cukup lebih tinggi akses ke informasi terhadap vaksinasi Covid 19.

Secara umum, makin tinggi status ekonomi responden, makin tinggi tingkat penerimaannya. Namun, penolakan tertinggi ditunjukkan responden yang tergolong ekonomi tertinggi $(20,2 \%)$ dan yang terendah ditunjukkan responden kurang cukup atau berpenghasilan rendah $(79,8 \%)$. Sebagian besar responden yang melakukan vaksin dalam keadaan terpaksa karena berhubungan dengan bantuan sosial PKH bagi masyarakat miskin sehingga memutuskan menerima vaksin dan tingkat 
keraguan cenderung menurun seiring meningkatnya status ekonomi.

Ada hubungan antara tingginya status ekonomi masyarakat dengan besarnya permintaan akan pemeliharaan kesehatan, terutama dalam hal pelayanan kesehatan. Pada masyarakat berpendapatan rendah, akan mencukupi kebutuhan barang terlebih dahulu setelah kebutuhan akan barang tercukupi maka akan memenuhi kebutuhan kesehatan. Biaya kesehatan umumnya meningkat sesuai dengan peningkatan status ekonomi. Orang yang berpendapatan cukup cenderung lebih sering dan lebih ekstensif dalam pelayanan kesehatan. Orang yang berpendapatan tinggi juga lebih sering memeriksa dan memelihara kesehatan disbanding dengan orang yang pendapatan kurang (Id et al., 2020).

Teori yang dikemukakan oleh Engel yang menyebutkan bahwa jika status ekonomi meningkat maka persentase pengeluaran untuk makanan akan semakin kecil dan dengan sattus ekonomi yang meningkat maka persentase pengeluaran untuk pendidikan, kesehatan, rekreasi, barang mewah dan tabungan akan semakin meningkat (Sunarti, 2012).

4. Akses

Berdasarkan hasil dari hasil penelitian di peroleh bahwa akses yang tidak terjangkau sebanyak 45 orang $(45,5 \%)$ dan yang terjangkau sebanyak 54 orang $(54,5 \%)$. Hal ini menandakan bahwa masyarakat di Kecamatan Wua-wua tidak mempersoalkan terkait akses dalam penerimaan vaksinasi Covid 19. Masyarakat mengungkapkan bahwa banyaknya layanan yang di buka untuk akses vaksinasi sehingga masyarakat tidak kesulitan untuk menjangkau vaksinasi tersebut.

Beberapa masyarakat mengungkapkan bahwa tidak terjangkau layanan vaksinasi itu terjadi di awal-awal pandemi covid 19 kemudian banyak di antara masyarakat yang beranggapan sebagai ibu rumah tangga yang tidak berkepentingan dengan kartu vaksinasi sehingga mereka menolak untuk akses vaksinasi covid 19. Pengetahuan masyarakat yang masih rendah ini menyebabkan petugas kesehatan kesulitan dalam mengajak masyarakat melakukan vaksinasi covid 19 untuk memutus mata rantai penularan demi kekebalan tubuh manusia secara sempurna.

Hasil penelitian yang sama diperoleh dari LiAumin (2021) yang menyatakan bahwa meskipun jarak tempat tinggal responden dengan layanan kesehatan jauh dan membutuhkan akses transportasi tidak menjadi kendala bagi responden untuk menjangkau layanan kesehatan, sehingga kunjungan responden yang tempat tinggalnya jauh dan dekat hampir sama (Liaumin, Rahman and Albar, 2021)

\section{F. PENUTUP}

1. Terdapat hubungan antara pengetahuan dengan Informasi vaksin dalam penerimaan vaksin covid 19 di kecamatan Wua-wua Kota Kendari yang di buktikan dengan hasil uji statistik chi square didapatkan nilai $p$ value $=0,026$.

2. Tidak ada hubungan antara pengetahuan dengan status ekonomi dalam penerimaan vaksin covid 19 di kecamatan Wua-wua Kota Kendari yang di buktikan dengan diperoleh uji statistik chi square didapatkan nilai $p$ value $=0,639$. 
3. Tidak ada hubungan antara pengetahuan dengan akses dalam penerimaan vaksin covid 19 di kecamatan Wua-wua Kota Kendari yang di buktikan dengan memperoleh nilai uji statistik chi square didapatkan $p$ value $=0,116$.

\section{G. DAFTAR PUSTAKA}

Achadi, Anhari Puspasari, A. (2021) 'Pendekatan Health Belief Model Untuk Menganalisis Penerimaan Vaksinasi Covid-19 Di Indonesia', Syntax Literate: Jurnal Ilmiah Indonesia, 6(8).

Elhadi, M. et al. (2021) 'Knowledge, attitude, and acceptance of healthcare workers and the public regarding the COVID-19 vaccine : a cross- sectional study', pp. 1-21.

Id, Y. L. et al. (2020) 'Understanding COVID-19 vaccine demand and hesitancy: A nationwide online survey in China', 28, pp. 1-22. doi: 10.1371/journal.pntd.0008961.

Kemenkes RI (2020) Pedoman Pencegahan dan Pengendalian Coronavirus Disease (Covid-19). Jakarta: Kementerian Kesehatan RI. doi: 10.33654/math.v4i0.299.

Liaumin, L. A., Rahman and Albar, K. (2021) 'Penerimaan Masyarakat Terhadap Vaksin Covid-19 Berdasarkan Teori Health Belief Model Di Kecamatan Poasia Kota Kendari.', Hospital Majapahit, 13(2), pp. 129-141.

Notoatmodjo, S. (2012) Promosi Kesehatan dan Perilaku Kesehatan. Jakarta: Rineka Cipta.

Satuan Tugas Penanganan Covid-19 (SATGAS COVID-19) (2021) Data Vaksinasi COVID-19., https://covid19.go.id/berita/data-vaksinasi-covid-19-update-31mei-2021.

Sunarti (2012) Pro Kontra Imunisasi. Yogyakarta: Hanggar Kreator.

WHO (2021) WHO COVID-19 Dashboard. Geneva: World Health Organization,.

Widayanti, L. P. and Kusumawati, E. (2021) 'Hubungan Persepsi Tentang Efektivitas Vaksin Dengan Sikap Kesediaan Mengikuti Vaksinasi Covid-19', Hearty, 9(2), pp. 78-84. 